\title{
Radikalisme Islam dalam Representasi Media di Thailand
}

\author{
Muhammad Fahmi \\ IAIN Surakarta \\ fahmielhalimy@gmail.com
}

\begin{abstract}
This article intends to look at how Islamic radical (ISIS) is represented in the Thai media. The method used in this study is critical discourse analysis method proposed by Theo van Leuwen which focuses on how actors in the inclusion and exclusion in the news media. This study concluded on: first, The Bangkok Post, represents ISIS identical and just as dangerous as Muslim rebels in southern Thailand. ISIS issue be a way to marginalize the Muslim rebels in southern Thailand region of the country bordering the Malay Peninsula. Second, the Pattaya Mail purposely did not link the issue of ISIS in southern Thailand among the Muslim fighters because they would only weaken efforts to build integration and large associations vis a vis ISIS. Pattaya Mail prefers macro strategy, which attempts to include as many friends to confront a common enemy: ISIS
\end{abstract}

\begin{abstract}
Abstrak
Kajian ini bermaksud untuk melihat bagaimana Islam Radikal (ISIS) direpresentasikan di media Thailand. Metode yang digunakan dalam kajian ini adalah metode analisis wacana kritis Theo van Leuwen yang berfokus pada bagaimana aktor ditampilkan (inklusi dan eksklusi) di media. Kajian ini menyimpulkan bahwa: Pertama, pada The Bangkok Post, merepresentasikan ISIS identik dan sama berbahayanya dengan pemberontak Muslim di Thailand selatan. Isu ISIS menjadi jembatan media untuk memarjinalkan para pejuang Muslim di wilayah Thailand Selatan. Kedua, Berbeda dengan The Bangkok Post, Pattaya Mail terlihat tidak mengaitkan isu ISIS dengan pejuang Muslim di Thailand Selatan. Hal ini antara lain disebabkan karena media tersebut hal tersebut justru akan melemahkan upaya untuk membangun integrasi dan asosiasi besar vis a vis ISIS. Pattaya Mail terlihat mencoba memasukkan sebanyak mungkin "teman" untuk menghadapi musuh bersama, yaitu : ISIS.
\end{abstract}

Keywords; media, representation, terrorism, discourse 


\section{A. Pendahuluan}

Belakangan ini dunia internasional dikejutkan dengan kemunculan kelompok radikal yaitu ISIS (Islamic State in Iraq and Syiria) yang mendeklarasikan pendirian negara Islam. Dengan mengusung narasi besar khilafah, kelompok ini terus merangsek dengan segenap militan yang siap melumat siapa saja yang menentang pendirian Islamic State tersebut. Kelompok ini tidak hanya mengancam masyarakat/negara non Islam tapi juga mengundang was-was bagi masyarakat/negara Islam yang tidak sepaham dengan mereka. Atas nama ajaran Islam, mereka melakukan praktik-praktik yang dianggap mencederai kemanusiaan seperti menculik dan mengeksekusi penganut agama yang berbeda paham dengan mereka baik muslim maupun non-muslim, warga lokal maupun asing, serta siapa saja yang menentang gerakan kelompok ini. Pada akhirnya, gerakan ISIS tersebut makin membuat citra Islam semakin terpuruk. Islam dianggap sebagai agama radikal.

Sebagai sebuah fakta sosial ${ }^{1}$, Islam dipahami dalam banyak versi, baik versi yang positif maupun negatif. Secara internal, bagi umat Islam, Islam tidak hanya diyakini sebagai the way of life tapi juga dipercaya sebagai agama penyempurna dari agama-agama samawi sebelumnya: Yahudi dan Nasrani. ${ }^{2}$ Karena itu, bagi umat Islam Islam adalah agama yang paling sempurna (the ultimate religion) dan agama yang paling benar (the true religion) $)^{3}$. Sementara secara eksternal, bagi non-muslim, utamanya Barat, Islam terkadang dipahami secara berbeda. Agama ini tidak hanya dilihat sebagai yang lain (the others), tapi juga terkadang dikaitkan dengan stigma, prejudice dan stereotype tertentu, seperti: sebagai agama yang pro pada kekerasaan, dan sarang terorisme. ${ }^{4}$

\footnotetext{
${ }^{1}$ Emile Durkheim, The Rules of the Sociological Method, (New York: Free Press, 1982), h. 50-59.

${ }^{2}$ ICRP (Indonesian Conference on Religion and Peace), Mempertanyakan Posisi Islam Terhadap Dua Saudaranya, (internet) $\quad$ http://icrponline.org/2014/08/28/mempertanyakan-posisi-islam-terhadap-dua-saudaranya-jilundang-pakar/>, (diakses pada 11 Maret 2015).

${ }^{3}$ Hal ini sebagaimana yang tertulis dalam kitab suci umat Islam; Al-Quran, Q.S.AlImran: 19 yang berbunyi "Innaddina 'Indallahil Islam" ( ان الدين عند الهه الاسلام) yang berarti "Sesungguhnya agama yang diridhai Allah hanyalah Islam".

${ }^{4}$ Sebuah hasil survei yang dipublikasikan harian The Guardian akhir Januari 2010 menyebutkan, kalangan politisi dan media massa di Inggris adalah penyebab kebencian masyarakat luas terhadap Islam. Menurut hasil survei yang dilakukan wartawan Inggris bernama Peter Oborne itu, politisi dan media Inggris kerap mengobarkan kebencian
} 
Stereotip tentang Islam tidak hanya tampak pada tataran sosiologis, namun juga merambah wacana akademik. ${ }^{5}$ Orientalisme misalnya sering dikritik sebagai kajian akademik yang dianggap bias karena kental berbalut praduga dan sakwasangka negatif pada Islam ${ }^{6}$. Edward Said (1997) telah memperlihatkan bagaimana "pengetahuan" yang dinamakan orientalisme ini sengaja dibuat dengan menyembunyikan motif non-akademis, yaitu apa yang disebut oleh Nietzsche "kehendak untuk berkuasa" (the will to power $)^{7}$. Inilah yang dalam bahasa Foaucault disebut dengan keterkaitan antara pengetahuan (knowledge) dan kekuasaan (power). Terjadi perselingkuhan antara pengetahuan (knowledge) dan kekuasaan (power) ${ }^{8}$. Jadi, pengetahuan membawa semacam "cacat bawaan" yaitu hasrat untuk berkuasa. Hasrat inilah yang oleh Spivak (1990) disebut sebagai bentuk neokolonialisme baru: suatu proyek imperialis yang berjalin-berkelindan dalam kertas kerja, wacana, teks dan narasi akademik Barat ${ }^{9}$. Akibatnya, ilmu pengetahuan kehilangan fungsi sejatinya: sebagai sarana yang mencerdaskan dan mencerahkan. Hal itu terjadi salah satunya diakibatkan karena ilmu pengetahuan bias kepentingan dan ideologi Barat. Proyek ilmu pengetahuan menjadi proyek neokolonialisme Barat yang bekerja lewat altar suci yang bernama dunia akademik

Demikian halnya dengan media, media-media global sering menarasikan Islam secara negatif, mengandung bias dan sarat dengan

terhadap umat Islam dengan menggambarkan umat Islam sebagai teroris yang berusaha melakukan Islamisasi di Inggris. Studi serupa juga dilakukan oleh pusat penelitian Muslim Eropa di Universitas Exeter London. Dari hasil studi yang disusun oleh perguruan tinggi ini ditemukan beberapa bukti empiris yang menjelaskan perilaku para politisi dan media Inggris itu. Menurut penelitian ini, meningkatnya sentimen masyarakat Inggris terhadap umat Islam dikarenakan pandangan dan pencitraan buruk yang dilakukan oleh keduanya, politisi dan media massa. Lihat (internet) $<$ http://www.republika.co.id/berita/dunia-islam/islam-mancanegara/10/07/09/123929inilah-wajah-islam-dalam-survei-di-dunia-barat>, (diakses 11 Maret 2015).

${ }^{5}$ Latifah Ibrahim Khaidar, Ketika Barat Memfitnah Islam, terj. Abdul Hayyie, (Jakarta: Gema Insani Press, 2005), h.25.

${ }^{6}$ Lihat, Edward Said, Covering of Islam: How the Media and Experts Determine How We See the Rest of the World, (Newyork: Vintage, 1997).

${ }^{7}$ St. Sunardi, Nietzsche, (Yogyakarta: LKiS, 1996), h..60.

${ }^{8}$ Lihat, Michel Foucault, Power/knowledge: Selected Interviews and Other Writings, 1972-1977, (New York: Harvester Wheatsheaf, 1980) dan Sara Mills, S., Michel Foucault, (London: Routledge, 2003), h. 67.

${ }^{9}$ Lihat, G.C.Spivak, The Post-Colonial Critic: Interviews, Strategies, Dialogies, (London: Routledge, 1990). 
stereotip tentang Islam ${ }^{10}$. Islam sering dijadikan pihak tertuduh yang harus disalahkan jika misalnya terjadi kasus-kasus kekerasan yang kebetulan dilakukan oleh orang Islam. Karenanya, kasus kekerasan tersebut kemudian dijadikan momentum untuk melakukan black campaign terhadap Islam. Dengan bantuan media massa dan media elektronik, kalangan Barat melakukan propaganda untuk mendeskriditkan Islam. Islam digambarkan agama yang beringas, haus darah, membenci kemajuan pihak lain, agama anti-HAM, agama teroris dan stigma negatif lainnya. ${ }^{11}$

Kasus ISIS yang marak akhir-akhir ini telah menjadi isu kontroversial yang tidak hanya terjadi dalam sorotan media global. Akan tetapi, hal tersebut juga telah menyita perhatian media-media di tanah air, baik media nasional maupun media lokal. Jika media-media global terkesan mendramatisasi kasus tersebut demi proyek black campaign terhadap Islam maka media-media di tanah air berbeda dengan wacana yang dikembangkan Barat tersebut. Media di Indonesia tidak melihat ISIS sebagai representasi Islam. Secara umum, dapat dikatakan media-media di tanah air menentang gerakan ISIS, menyorot aksi-aksi brutal yang dilakukan oleh ISIS seperti penghancuran masjid-mesjid dan tempattempat suci agama yang dianggap bertentangan dengan paham mereka. Demikian halnya dengan sikap media-media di negara-negara yang berpenduduk mayoritas Islam di Asea Tenggara, seperti Malaysia dan Brunei. Bagi mereka ISIS lebih dilihat sebagai gerakan politik ketimbang gerakan Islam: ISIS tidak merepresentasikan Islam.

Menjadi menarik untuk melihat bagaimana sikap media-media di negara-negara yang berpenduduk mayoritas non-Muslim di kawasan Asia Tenggara (ASEAN) seperti Singapura, Thailand, Kamboja, Philipina dan lain-lain. Apakah media-media mereka menarasikan Islam sama seperti Barat yang melihat Islam sebagai agama teror? Atau sama seperti negaranegara yang berpenduduk muslim lainnya yang melihat ISIS bukan mengekspresikan Islam? Berangkat dari hal di atas menjadi menarik untuk mengkaji bagaimana media di Thailand menyajikan wacana ISIS

\footnotetext{
${ }^{10}$ Lihat, Elzain Elgambri, Islam in The British Broadsheets: The Impact of Orientalism on Representation of Islam, (Reading UK: Itaca, 2008).
${ }^{11}$ Alwi Shihab, 2014,Menghalau Islam Phobia, http://www.alwishihab.com/inspirasi/2014/9/21/menghalau-islamophobia ， diakses pada 19 Maret 2015.


tersebut? Bagaimana media dari negara Budhis, yang masih menyisakan konflik dengan penduduk Islam di kawasan Selatan, melihat isu tersebut? Bagaimana media melakukan politik pemaknaan pada isu yang terkait gerakan ISIS? Artinya, bagaimana media merepresentasikan gerakan dan aksi-aksi yang dilakukan ISIS?

Sebagai kajian akademis, tulisan ini bertujuan untuk melihat sejauh mana sikap media Thailand dalam melihat gerakan dan aksi-aksi ISIS dan sejauhmana hal tersebut mempengaruhi cara pandang mereka dalam mempersepsikan umat Islam dan ajarannya. Hal ini penting, karena sikap media di Thailand tersebut sangat mempengaruhi kondisi sosial dan masa depan umat Islam di Thailand Selatan. Hal ini dikarenakan media bisa mempengaruhi masyarakat ${ }^{12}$, jika media bias dan mengonstruksikan Islam secara negatif maka masyarakat dapat terpengaruh oleh media. Pada akhirnya, stigma tersebut akan merusak segenap upaya semua pihak untuk meredakan ketegangan dan konflik di wilayah Selatan. Kampanye rekonsiliasi nasional dan upaya-upaya untuk menumbuhkan saling kepercayaan (mutual understanding) antara pihak yang selama ini berkonflik akan sulit di tengah kampanye media yang memelintir isu ISIS untuk stigmatisasi umat Islam di wilayah Selatan.

Untuk mengkaji hal tersebut penulis menggunakan teori representasi Stuart Hall (1997) yang memokuskan pada bagaimana produksi makna dari pelbagai konsep pemikiran disampaikan lewat bahasa media ${ }^{13}$. Begitu juga teori ideological state apparatus Althusser, teori wacana Media Fairclough dan Chomsky. Konsep teori tersebut digunakan untuk membongkar wacana dan ideologi media, bagaimana makna-makna yang ingin disampaikan pada khalayak, bagaimana proses maupun produk dari pemaknaan suatu tanda, dan bagaimana media mempengaruhi cara pandang publik ${ }^{14}$. Teori ini memandang bahwa lewat bahasa (simbol-simbol dan tanda tertulis, lisan, atau gambar) dapat mengungkapkan pikiran, konsep, dan ide-ide tentang sesuatu. ${ }^{15}$ Hall meyakini bahwa ada bias dengan representasi kelompok minoritas dalam media. Teori Representasi ini digunakan untuk melihat bahwa apa yang

\footnotetext{
${ }^{12}$ Noam Chomsky, Hegemony or Survival, (New York: Metropolitan Books, 2003), h.6.

13 Stuart Hall, Representation: Cultural Representations and Sgnifying Practices. (London Thousand Oaks, California: Sage, 1997), h..7.

${ }^{14}$ Chris Barker, The SAGE Dictionary of Cultural Studies, (London: Sage, 2009), h. 268.

${ }^{15}$ Ibid, h. 15 .
} 
direpresentasikan media seperti berita bukanlah semata-mata fakta, tapi "fakta" yang sudah dikonstruksi media. Dan tentu saja, makna yang yang diinginkan itu sesuai dengan kepentingan media.

Dalam konteks ini, representasi Islam dalam media Thailand juga harus diletakkan dalam posisi demikian: bahwa media-media di Thailand sangat mungkin bias dan tidak netral dalam merepresentsikan Islam. Islam yang dikonstruksikan media tentu sangat dipengaruhi oleh faktor-faktor nilai-nilai, ideologi dan aneka kepentingan media dan kelompok yang berkuasa. Pemberitaan kasus ISIS misalnya, sangat tergantung pada dimensi-dimensi tersebut, sehingga jika kepentinganya untuk menstigmatisasi gerakan Islam sebagai gerakan radikal yang harus ditumpas, maka kasus ini dapat menjadi sumber legitimasi.

Di samping itu, tulisan ini juga menggunakan pendekatan analisis wacana (discourse). Dengan pendekatan ini diharapkan akan dapat singkap selubung kepentingan di balik konstruksi pemberitaan media tentang Islam. Islam seperti apa yang sedang direpresentasikan media? Bagaimana media-media Thailand merepresentasikan kasus yang menyangkut ISIS? Ini akan dilihat dengan pendekatan analisis wacana Theo Van Leeuwen, yang secara umum bertujuan untuk melihat pihakpihak dan aktor, seseorang atau kelompok atau para pihak ditampilkan dalam pemberitaan. ${ }^{16}$ Dalam konteks kajian ini untuk melihat bagaimana isu ISIS ditampilkan dalam pemberitaan di Media. Ada dua pusat perhatian yaitu: Exclusion, yang menyangkut bagaimana suatu aktor, seseorang atau sekelompok dikeluarkan dalam sebuah artikel berita, dan Inclusion, yang berkaitan dengan bagaimana aktor atau pihak-pihak ditampilkan dalam berita. Berita diambil dari artikel tentang ISIS pada dua surat kabar: The Bangkok Post dan Pattaya Mail. Kemudian artikel tersebut dianalisis dengan menggunakan analisis wacana Van Leeuwen.

${ }^{16}$ Theo Van Leeuwen, The Representation of Social Actors in Discourse, dalam Texts and Practices: Readings in Critical Discourse Analysis, ed. C. R.,Caldas-Coulthard, \& M. Coulthard, (London: Routledge, 1996,) h. 32-40. 
Tabel 1: Teknik Eksklusi dan Inklusi yang dimodifikasi (Khuriyati, 2013) $)^{17}$

\begin{tabular}{|c|c|}
\hline Teknik & Yang ingin dilihat \\
\hline Eksklusi & $\begin{array}{l}\text { a. Apakah ada penghilangan aktor dalam } \\
\text { pemberitaan? (Pasivasi). } \\
\text { b. Apakah ada upaya media untuk } \\
\text { mengedepankan aktor tertentu dan } \\
\text { menghilangkan aktor lain? (Nominalisasi) } \\
\text { c. Bagaimana strategi yang dilakukan untuk } \\
\text { menyembunyikan atau menghilangkan aktor } \\
\text { sosial tersebut? Apakah subjek atau aktor } \\
\text { dihilangkan dengan memakai anak kalimat? } \\
\text { (Penggantian Anak Kalimat) }\end{array}$ \\
\hline Inklusi & $\begin{array}{l}\text { a. Bagaimana para aktor ditampilkan dalam teks } \\
\text { berita secara berbeda? (Diferensiasi/ } \\
\text { indeferensiasi) } \\
\text { b. Apakah suatu peristiwa atau aktor sosial } \\
\text { ditampilkan dengan memberi petunjuk yang } \\
\text { konkrit? (Objektivasi/Abstraksi) } \\
\text { c. Apakah aktor ditampilkan apa adanya atau } \\
\text { media mengkategorisasi aktor tersebut? } \\
\text { (Nominasi/Kategorisasi) } \\
\text { d. Apakah aktor digambarkan dengan identitas } \\
\text { buruk atau sterotype tertentu? (Nominasi/ } \\
\text { Identifikasi) } \\
\text { e. Apakah peristiwa atau aktor ditampilkan } \\
\text { dengan jelas atau tidak (anonim)? (Deter- } \\
\text { minasi/Indeterminasi) }\end{array}$ \\
\hline
\end{tabular}

\section{B. Islam Minoritas di Thailand}

Thailand Selatan merupakan sejumlah kawasan di Thailand yang berbatasan dengan Semenanjung Malaysia, terdiri dari 5 Propinsi: Narathiwat, Pattani, Yala, Songkhla dan Satun. Mayoritas penduduknya

\footnotetext{
${ }^{17}$ Khuriyati, Analisis Wacana Terhadap Teks Berita Tuntutan Pembubaran FPI pada SKH Kompas edisi Februari 2012, "Skripsi”, (Yogyakarta: UIN Sunan Kalijaga, 2013,), h.20.
} 
adalah orang Melayu dan beragama Islam meskipun Thailand diperintah oleh kerajaan Buddha.

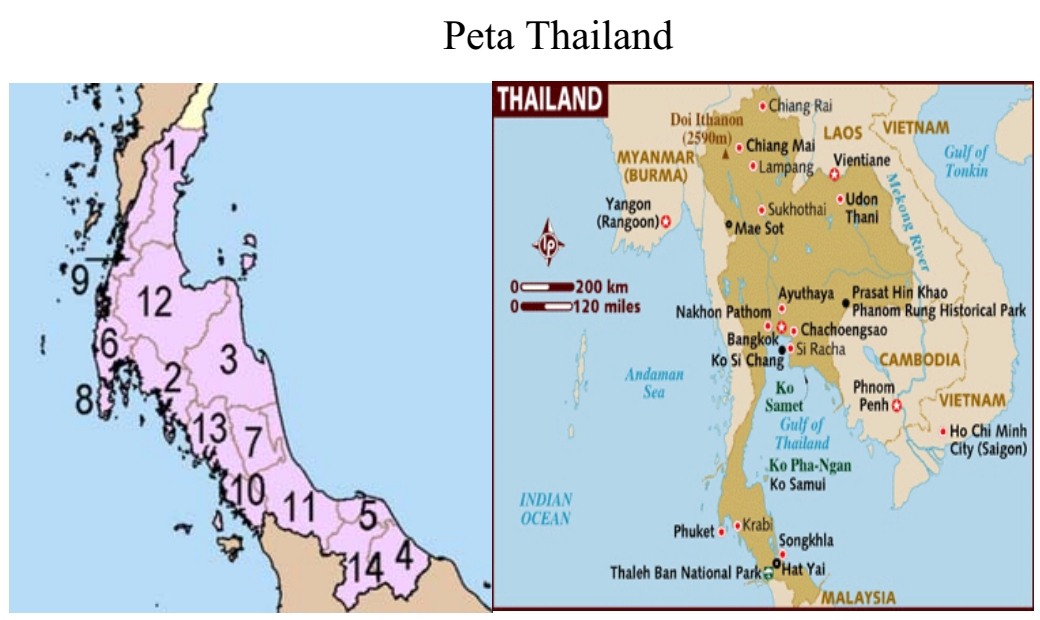

Sumber: https://id.wikipedia.org/wiki/Thailand Selatan

Jika dilihat pada peta di atas terlihat jelas wilayah-wilayah yang berbatasan langsung dengan Malaysia yaitu Narathiwat (4), Pattani (5), Satun (10), Songkhla (11) dan Yala (14). Kondisi ini menimbulkan konflik identitas, sejarah dan sumber daya alam, sebagai akibat perbedaan etnik, agama, sejarah dan geografis Thailand Selatan dengan Bangkok ${ }^{18}$. Jumlah penduduk Islam di Thailand menurut sensus 1979, jumlah mereka adalah 977.282 jiwa atau 2,84\% dari seluruh penduduk Thailand yang sekitar 45 juta jiwa. Dan ada sekitar enam juta Muslim di Thailand pada tahun $1982^{19}$.

Secara historis, wilayah-wilayah tersebut dulu termasuk dalam bagian kerajaan Pattani Raya, namun pada tahun 1785 M pasukan Siam (Ayuthaya, nama lain dari Thailand) dibawah pimpinan Phraya Chakri menyerang Patani hingga berhasil ditahlukkan pada bulan November 1786 M. Kekalahan ini benar-benar menghancurkan harkat dan martabat rakyat dan kerajaan Patani. Pada tahun 1826 M, penaklukan Siam

\footnotetext{
${ }^{18}$ Baiq L S W Wardhani, Globalisasi dan konflik etnis (Surabaya : Cakra Studi GlobalStrategis (CSGS) Publisher, 2010) h.14.

${ }^{19}$ Laili Maftukha, Gerakan Pembebasan Islam Pattani di Thailand Selatan pada tahun 1973-1982, Skripsi, (Surabaya, Fakultas Adab Institut Agama Islam Negeri Sunan Ampel, 2011), h.3.
} 
terhadap Patani mendapat pengakuan Britania Raya dan dalam usahanya untuk mengokohkan kedudukannya di Patani, pada tahun 1902 Kerajaan Siam melaksanakan Undang-undang Thesaphiban, yang menghapus sistem pemerintahan kesultanan Melayu. Dengan ditandatanginya Perjanjian Bangkok pada tahun 1909, Patani telah diakui oleh Britania sebagai bagian dari jajahan Siam walaupun tanpa mempertimbangkan keinginan penduduk asli Melayu Patani ${ }^{20}$

Runtuhnya kerajaan Pattani sebagai suatu kelompok etnik dan berbahasa Melayu serta beragama Islam mengakibatkan penduduknya Melayu di wilayah tersebut dipaksa menjadi suatu bagian yang integral dari masyarakat Thai yang berbeda secara etnik, bahasa dan agama. Walaupun pemerintah Thailand aktif mempromosikan kebijakan asimilasi, mayoritas kaum muslim Melayu di wilayah tersebut tetap mempertahankan pertalian etnis dan kultural yang kuat dengan Muslim Malaysia tetangganya di selatan. Kebijakan asimilasi pemerintah Thailand banyak menyebabkan gerakan keagamaan dan etnis separatis serta konflik identitas di antara Muslim Melayu di Thailand. ${ }^{21}$

Akibatnya, meletuslah bebagai peristiwa seperti pemberontakan setelah ditangkapnya Haji Sulong, tokoh Gerakan Rakyat Patani (GPR) tahun $1948^{22}$, Barisan Revolusi Nasional (BRN) pada tahun 1963 yang dipimimpinya Abdul Karim Hassan. ${ }^{23}$ Sejak awal tahun 2004, beberapa insiden kerusuhan dan huru hara telah melanda Thailand Selatan, terutama di wilayah-wilayah Narathiwat, Yala dan Patani. Penduduk tidak merasa senang dengan reaksi keras pemerintah Bangkok terhadap aktifitas gerakan pejuang kemerdekaan tersebut. Mereka juga tidak puas dengan beberapa kebijakan kerajaan pusat yang memperlakukan mereka dengan cara berbeda dari kaum etnis Thailand. Ini mendorong munculnya eskalasi radikalisme. Tekanan politik penguasa dapat menjadi salah satu akar radikalisme. ${ }^{24}$

Sementara, menurut Laili Maftukha akar dari konflik yang terjadi di Thailad Selatan adalah karena perbedaan kebudayaan dan rasa benci antara yang memerintah dan yang diperintah. Konflik seperti itu

\footnotetext{
${ }^{20}$ Malik Ibrahim, Seputar Gerakan Islam di Thailand Suatu Upaya Melihat Faktor Internal dan Eksternal, Jurnal SOSIO-RELIGIA, Vol. 10, No.1, 2012, h.141.

${ }^{21}$ Ibid, h. 134

${ }^{22}$ Ibid, h. 145.

${ }^{23}$ Ibid, h. 147.

${ }^{24}$ Sun Choirol Ummah, Akar Radikalisme Islam di Indonesia, Jurnal Humanika, Vol. 2. No. 12. 2012, h. 118.
} 
menyebabkan timbulnya organisasi-organisasi yang ingin membebaskan diri dari pemerintahan Thailand, organisasi tersebut adalah Nasional Liberation Front of Pattani (NLFP) atau Barisan Nasional Pembebasan Pattani, Liberation Front of Republic Pattani (LFRP) atau Barisan Revolusi Nasional (BRN), dan Pattani United Liberation Organization (PULO) atau Pertumbuhan Persatuan Pembibasan Pattani (PPPP $)^{25}$.

Aksi-aksi tersebut menjadi justifikasi pemerintah Bangkok untuk menstigmatisasi gerakan Islam sebagai gerakan radikal dan ekstrem. Bangkok, terutama di masa pemerintahan junta militer, mempropaganda setiap aksi keras mereka terhadap pemberontak sebagai upaya untuk menegakkan kemanan dari gangguan kaum teroris-radikal, dan menuding gerakan-gerakan Islam sebagai yang hendak mengacau kemananan dan mengancam keutuhan negara. Propaganda dan stigma negatif tersebut terus direproduksi pemerintah Bangkok, termasuk di dalam media. Hingga sampai saat ini wilayah selatan Thailand tersebut masih sering meletus aksi-aksi perlawanan. Pada tahun 2015 penulis berkunjung ke wilayah Yala. Pada malam pertama kunjungan tersebut terjadi peristiwa pemboman kurang lebih $1 \mathrm{~km}$ dari hotel tempat menginap penulis. Pada waktu itu diberlaku jam malam, setelah makan malam di luar kami dilarang keluar dari hotel hingga pagi hari. Sekembali ke hotel dari makan malam, kami diberitahu mitra lokal bahwa telah terjadi pemboman tidak jauh dari hotel tersebut.

Reproduksi stigma negatif terhadap Islam lewat kanal media dengan memanfaatkan isu ISIS, dalam media-media di Thailand, jelas tidak hanya berdampak pada upaya rekonsiliasi nasional di Thailand yang menyangkut relasi Negara dan umat Islam, khususnya di kawasan konflik Thailand Selatan yang mencakup seluruh kawasan Pattani Raya, tapi juga akan berimplikasi sebagai berikut: Pertama, massifikasi citra negatif Islam di mata rakyat Thailand, utamanya dari mereka yang bukan beragama Islam. Jika media global relatif berhasil mengonstruksi Islam secara negatif sehingga menimbulkan Islam phobia di pelbagai kawasan di dunia, maka stigmatisasi Islam lewat media-media Thailand dikhawatirkan akan melahirkan munculnya paronia terhadap umat dan ajaran Islam. Umat Islam akan dipersepsikan rakyat Thailand sebagai

\footnotetext{
${ }^{25}$ Laili Maftukha, Gerakan Pembebasan Islam Pattani di Thailand Selatan pada tahun 1973-1982, Skripsi, (Surabaya, Fakultas Adab Institut Agama Islam Negeri Sunan Ampel, 2011), h.70.
} 
monster jahat yang haus darah, sebagaimana yang mereka lihat dan dengar dari media yang memberitakan tentang ISIS.

Kedua, generalisasi Islam identik dengan ISIS. Rakyat Thailand akan memandang bahwa warga muslim, hatta muslim Thailand sendiri, sama dan identik dengan ISIS dan karena itu muncul persepsi bahwa kedua-keduanya, Islam dan ISIS, sama bahayanya. Akibatnya, umat Islam di Thailand akan semakin terisoliasi dari interaksi sosial yang normal dan tanpa curiga dalam masyarakat Thailand. Kondisi ini pada akhirnya justru menjadi pemicu pelbagai persoalan sosial lainnya, seperti munculnya disharmoni dan konflik sosial yang komunal sebagaimana yang menimpa kaum muslim Rohingya di Myanmar dan kaum muslim Ughyur di Republik Rakyat Tionghoa (RRT).

Isolasi sosial justru akan mengakibatkan apa yang disebut oleh Georg Simmel ${ }^{26}$ sebagai "konflik dan integrasi". Pada satu sisi kaum Muslim di Thailand akan berkonflik vis a vis dengan pemerintah Thailand sementara pada sisi yang lain muslim Thailand akan terintegrasi dalam satu identitas: yaitu kaum Muslim yang memberontak pada despotisme pemerintah kafir: negara Thailand. Kalau ini ini terjadi, berarti media telah menjadi provokator sebuah konflik komunal yang bersifat massif. Berbeda dengan muslim Myanmar dan China, kaum muslim di Thailand, utamanya yang terhimpun dalam lima propinsi di kawasan Selatan Thailand, memiliki kekuatan yang tidak dapat disepelekan.

Kawasan selatan Thailand memiliki kekayaan alam berupa tanah yang subur, hasil pertanian dan bahan-bahan mentah (raw material) yang amat dibutuhkan dalam menyokong perekonomian Thailand, di luar pariwisata yang mulai meredup pasca krisis ekonomi di Eropa dan mewabahnya virus Mers di negara tersebut. Posisi tawar kaum muslim di Selatan jauh lebih besar, sehingga jika terjadi konflik yang paling menderita adalah Bangkok: hilangnya "tambang emas" ekonomi mereka: eco-farming.

\section{Islam dalam the Bangkok Post}

The Bangkok Post merupakan sebuah surat kabar harian berbahasa Inggris yang terbit di Bangkok, Thailand, ---negara di mana penyensoran media menjadi sebuah kelaziman. Surat kabar ini merupakan koran tertua

${ }^{26}$ Georg Simmel, On Individuality and Social Forms, (Chicago: University of Chicago Press). 
Thailand. Terbit pertama kali terbit pada tanggal 1 Agustus 1946. The Bangkok Post menggambarkan dirinya sebagai relatif bebas. Tetapi ada contoh di mana koran ini telah melakukan kebijakan sensor untuk menghindari kontroversi atau konflik dengan penguasa, termasuk kepatuhan terhadap regulasi hukum yang ketat di negara itu, yang melarang kritik terbuka terhadap penguasa, terutama kepada keluarga raja (Thai Royal Family). Contoh lain adalah "diamnya" koran ini selama Perang Vietnam karena adanya pangkalan Angkatan Udara AS di Thailand. Berita yang mengkritik Amerika tidak diberi ruang dalam media ini. The Bangkok Post pernah terkenal di kalangan ekspatriat untuk mingguan kolom Nite $O w l$ yang meliputi kehidupan malam Bangkok. Namun tahun 2004, liputan ini dihentikan karena pertimbangan lebih dari setengah dari total pembacanya adalah warga negara Thailand.

The Bangkok Post didirikan oleh Alexander MacDonald, seorang mantan perwira OSS (Office of Strategic Services) USA, dan Prasit Lulitanond, elit lokal. Thailand pada saat itu adalah satu-satunya negara di Asia Tenggara yang memiliki Kedutaan Uni Soviet, karena itu Kedutaan besar Amerika merasa membutuhkan sebuah surat kabar yang pro-Amerika untuk melawan pengaruh Soviet. Desas-desus beredar bahwa konon media ini mendapat pembiayaan langsung dari Departemen Luar Negeri AS atau mungkin bahkan OSS itu sendiri, meskipun tidak ada bukti ini.

Alex MacDonald meninggalkan Thailand setelah kudeta militer pada awal 1950-an, dan surat kabar itu kemudian dipimpin oleh, Lord Thomson Roy, pemilik koran Amerika The Times dan The Sunday Times. Pemegang saham utama di Post Publishing termasuk keluarga Chirathivat (pemilik Grup Central), South China Morning Post dari Hong Kong dan GMM Grammy Pcl, perusahaan media dan hiburan Thailand terbesar. The Bangkok Post mempekerjakan (April 2015) 179 wartawan, termasuk wartawan, Rewriters, editor, sub-editor, fotografer, dan desainer. Dua puluh sembilan warga asing bekerja sebagai sub-editor dan cetak dan berita editor digital. Paul Ruffini, warga negara Australia bertindak sebagai editor. Semua staf wartawan adalah warga negara Thailand sedangkan staf asing berperan dalam menulis (rewriter) berita surat kabar, olahraga, bisnis, dan fitur-fitur lainnya ${ }^{27}$.

${ }^{27}$ Lihat di https://en.wikipedia.org/wiki/Bangkok_Post . 
Dari latar belakang media di atas paling tidak ada dua catatan yang bisa dikaitkan dengan konteks representasi Islam yang akan dibahas di sini yaitu: Pertama, sejak berdirinya The Bangkok Post memang didesain untuk alat propaganda, dalam hal ini Amerika, untuk konteks Perang dingin dengan Sovyet ketika itu. Kalau militer adalah aparat coersif maka media adalah aparat ideologisnya (ideological state apparatus) ${ }^{28}$. Sebagai alat propaganda tentu saja koran ini akan sangat bias dengan kepentingan Amerika dan sekutunya. Kepentingan yang sama masih relevan saat ini meski konteksnya berubah: jika dulu konteks Perang Dingin maka saat ini konteks perang terhadap terorisme global, dimana ISIS sebagai aktor terkininya.

Kedua, Sejak berdiri koran ini di samping merepresentasikan kepentingan Amerika (baca: Barat) tapi juga merepresentasikan elit Bangkok, yang menjadi rekan kongsi maupun staf dari eksapatriat Barat. Kepentingan Barat yang anti terhadap Islam dan Penguasa Bangkok yang "jengah" dengan pejuang pembebasan Thailand Selatan bertemu pada kasus ISIS. Pada akhirnya ini jelas memiliki pengaruh pada konstruksi pemberitaan media tersebut pada kasus-kasus yang menyangkut Islam.

Hal itu dapat kita lihat pada pemberitaan yang berjudul Nabbed Thai students suspected of 'IS link'29, (Tertangkap, mahasiswa Thailand yang diduga Militan ISIS). Berikut hasil analisa Wacana model Theo Van Leuween pada artikel tersebut:

Tabel 2: Hasil Analisa Wacana pada The Bangkok Post

\begin{tabular}{|l|l|l|}
\hline \multicolumn{1}{|c|}{ Judul Artikel } & \multicolumn{1}{|c|}{ Media } & \multicolumn{1}{c|}{$\begin{array}{c}\text { Bagaimana Aktor/ Subjek } \\
\text { diwacanakan }\end{array}$} \\
\hline $\begin{array}{l}\text { Tertangkap, } \\
\text { mahasiswa Thailand } \\
\text { yang diduga Militan } \\
\text { ISIS }\end{array}$ & $\begin{array}{l}\text { The Bangkok } \\
\text { Post }\end{array}$ & $\begin{array}{l}\text { Pertama, judul artikel tersebut juga } \\
\text { sengaja dibuat tidak jelas terutama pada } \\
\text { subjek yang terkait dengan } \\
\text { "penangkap". Siapa yang menangkap? } \\
\text { Subjek dibiarkan anonim dalam judul } \\
\text { tersebut. Tujuannya jelas, agar } \\
\text { perhatian pembaca bisa fokus pada } \\
\text { subjek mahasiswa (Islam) saja bukan } \\
\text { pada subjek lain. }\end{array}$ \\
\hline
\end{tabular}

\footnotetext{
${ }^{28}$ Lihat, Louis Althusser, Ideology and Ideological State Apparatus (Notes Towards an Investigation) ed. S. Zizek dalam Mapping Ideology, (London - Newyork: Verso, 2012). ${ }^{29}$ Artikel dapat dilihat di http://www.bangkokpost.com/archive/nabbed-thai-studentssuspected-of-is-link/589885.
} 


\begin{tabular}{|l|l|}
\hline & Kedua, pada artikel ini The Bangkok \\
Post menggunakan strategi eksklusi- \\
pasivasi. Artinya, ada upaya untuk \\
memarjinalkan aktor tertentu dan \\
menghilangkan aktor lain. Dalam hal \\
ini, subjek yang dimarjinalkan adalah \\
Mahasiswa (Muslim) Thailand, \\
sementara subjek yang dibuat kabur \\
dan tidak jelas adalah "penangkap dan \\
sumber-sumber intelijen". \\
Ketiga, dengan menghadirkan \\
informasi dari subjek anonim: \\
"sumber-sumber intelijen", subjek \\
mahasiswa digambarkan sebagai yang \\
telah terlatih dan terlibat dengan ISIS \\
serta berlatar sebagai orang (Islam) \\
yang berasal dari kawasan Selatan \\
Thailand. Mestinya sumber anonim ini \\
harus jelas sehingga sehingga bisa \\
dibedakan antara gossip atau fakta. Ini \\
rawan untuk mengging opini dan trial \\
by pers.
\end{tabular}

Pertama, judul artikel di atas terlihat sengaja dibuat tidak jelas terutama pada subjek yang terkait dengan "penangkap". Siapa yang menangkap? Subjek dibiarkan anonim dalam judul tersebut. Tujuannya jelas, agar perhatian pembaca bisa fokus pada subjek mahasiswa (Islam) saja bukan pada subjek lain. Dalam bahasa Teo Van Leeuwen strategi ini disebut dengan teknik pasivasi, dimana subjek tertentu sengaja dihilangkan oleh media untuk melakukan politik pemaknaan tertentu sesuai yang diingini media.

Dalam konteks ini subjek "penangkap" dianggap akan mengganggu konsentrasi pembaca manakalah dihadirkan dalam judul. Jika subjek dihadirkan, misalnya dibuat judul "Polisi Pakistan Menangkap Mahasiswa Thailand Yang diduga Terlibat ISIS", tentu perhatian pembaca akan "tercuri" oleh Polisi Pakistan. Akan berbeda jadinya ketika polisi Pakistan dihilangkan, maka seketika fokus beralih pada subjek yang lainnya yaitu mahasiswa Thailand. Dalam benak pembaca muncul secara cepat pertanyaan mahasiswa mana? Dan seketika lantas muncul secara otomatis jawabannya: mahasiswa mana lagi yang mungkin terkait dengan ISIS kalau tidak mahasiswa Islam dari kawasan Selatan. Inilah politik representasi The Bangko Post: marjinalisasi dan stigmatisasi mahasiswa 
muslim dari kawasan Selatan negara tersebut sebagai subjek yang terkait dengan ISIS. Institusi-institusi media sering dianggap bersikap netral dalam menyediakan ruang bagi wacana publik. Fairclough menunjukkan kesalahan dari asumsi tersebut, dan menggambarkan konstruksi discourse dan representasi media justru dilakukan demi agenda setting media, kepentingan dan ideologi kelompok dominan ${ }^{30}$.

Kedua, dalam artikel di atas, The Bangkok Post telah melakukan eksklusi pasivasi, yaitu adanya upaya untuk memarjinalkan subjek tertentu dan sebaliknya menghilangkan subjek lainnya. Dalam konteks artikel di atas subjek yang dimarjinalkan adalah Mahasiswa Thailand, sementara subjek yang dibuat kabur dan tidak jelas adalah "penangkap dan sumber-sumber intelijen". Pada subjek yang pertama, marjinalisasi sudah terlihat dari aspek judul "Tertangkap, mahasiswa Thailand yang diduga militan ISIS'. Judul ini sudah memperlihatkan stressing media pada subjek yang menyangkut mahasiswa, sehingga diharapkan pembaca hanya fokus pada subjek ini dan secara spontan terbentuk garis imajiner yang mengubungkan antara mahasiswa dan IS atau ISIS. Dengan konstruksi judul tersebut pembaca sudah bisa menebak mahasiswa mana yang bisa dikaitkan dengan ISIS. Meski tidak dijelaskan mahasiswa mana, dalam benak pembaca mestilah muncul citra mahasiswa Islam dari Thailand Selatan. Mengapa? Karena judul sudah mengkoneksikannya dengan ISIS. Dengan demikian, dari aspek judul saja sudah terlihat The Bangkok Post sudah melakukan praktik representasi yang mengarah pada marjinalisasi mahasiswa Islam yang berasal dari Thailand Selatan. Hal ini sebagaimana yang dikatakan Stuart Hall bahwa dalam sistem representasi makna-makna diproduksi lewat bahasa media ${ }^{31}$.

Ketiga, sebenarnya dari judul saja sudah dapat diketahui posisi ideologis The Bangkok Post sebagaimana yang telah dipaparkan di atas. Pertanyaanya kemudian; bagaimana dengan isi beritanya? Apakah media memaparkan fakta secara berimbang? Memang, jika dibaca secara sekilas, terkesan media ini memberitakan secara berimbang dan adil (cover both side). Bahkan diterangkan dalam artikel ini bahwa sumber resmi Thailand menyatakan mahasiswa tersebut tidak punya kaitan dengan ISIS dan kelompok militan di Selatan. Namun, dengan menghadirkan subjek yang

\footnotetext{
${ }^{30}$ Lihat, Norman Fairclough, Language and Power (London: Longman, 1989).

31 Stuart Hall, Representation: Cultural Representations and Sgnifying Practices. (London Thousand Oaks, California: Sage, 1997), h.7.
} 
misterius, "sumber-sumber intelijen" membuat keberimbangan pemberitaan tersebut menjadi hanya sekedar kamuflase media untuk menyembunyikan bias media.

Dengan mengatas-namakan "sumber-sumber intelijen" inilah media ini kembali melakukan praktik marjinalisasi mahasiswa muslim tersebut. Melalui "corong" sumber-sumber intelijen, subjek digambarkan sebagai mahasiswa yang telah terlatih dan terlibat dengan ISIS. Marjinalisasi semakin sempurna ketika subjek digambarkan sebagai orang (Islam) yang dikenal karena kesalehan agama dan berasal dari kawasan Selatan Thailand. The Bangkok Post, melalui artikel di atas, merepresentasikan stigma dan stereotip negatif kepada Islam dan orangorang Islam di kawasan Selatan Thailand. Kesimpulan yang dapat ditarik dari artikel di atas adalah The Bangkok Post tidak dapat melepaskan diri dari sterotipe dan stigma negatif pada Islam. Pengalaman dan interaksi masyarakat Thailand pada Islam yang terlanjur berawal dari konflik umat Islam di kawasan Thailand Selatan, telah ikut membentuk imaji mereka tentang Islam.

Tentu saja, gambaran Islam yang tertanam dan muncul dalam dalam pra sadar mereka adalah sangat dipengaruhi oleh pengalaman konflik mereka dengan kaum muslim di kawasan yang berbatasan dengan Malaysia tersebut. Pada akhirnya, hal tersebut juga akan mempengaruhi media. Media menjadi tidak netral. Media menjadi alat kepentingan kekuasaan. Hal tersebut sebagaimana yang dikatakan Althusser media menjadi "aparat ideologis media" (ideological state apparatus). The Bangkok Post, meskipun sebagai lembaga pers yang seharusnya netral, menjadi terlihat sangat bias dan pro kepentingan Barat dan Bangkok. Media ini telah menjadi corong penguasa dalam rangka ---meminjam oleh Chomsky (2003) "the manufacture of consent", memproduksi persetujuan atau konsesus sosial melalui public opinions ${ }^{32}$. Hal tersebut menggambarkan manipulasi pemikiran publik untuk mendukung status quo. Dalam konteks ini tentunya untuk mendukung status-quo Bangkok untuk memenangkan klaim pada kawasan Selatan yang subur dan penghasil raw material yang berlimpah sehingga menjadikan negeri Gajah tersebut dikenal sumber buah "super" yang serba "Bangkok" (padahal ditanam dan berasal dari wilayah "Pattani Raya").

${ }^{32}$ Noam Chomsky, 2003, Hegemony or Survival, (New York: Metropolitan Books), h.6. 


\section{Islam dalam Pattaya Mail}

Pattaya Mail adalah surat kabar berbahasa Inggris pertama di Pattaya dan pesisir Timur dari Thailand. Edisi perdana surat kabar ini terbit pada tanggal $23 \mathrm{Juli}$, 1993. Media ini mengklaim bahwa tujuan dari surat kabar adalah untuk mewakili daerah secara adil dan objektif dengan mengungkapkan kebenaran. Pattaya Mail telah menikmati pertumbuhan yang stabil sejak tahun 1993, dan basis pembaca, yang semula terbatas, telah diperluas untuk mencakup seluruh pesisir Timur dan bahkan ke daerah lain di Inggris (via internet). Pattaya Mail semula merupakan surat kabar komunitas yang informatif dan mengangkat persoalan-persoalan yang terjadi di masyarakat, kegiatan sosial, olahraga lokal, dsb.

Pattaya Mail kemudian memperluas bisnisnya melalui World Wide Web (internet). Media ini menjadi media konvergensi antara media elektronik dengan media paper. Versi elektroniknya berupa TV Show, disiarkan pada jaringan TV kabel di wilayah Chonburi dan Pattaya. Penerbit dari Pattaya Mail tidak hanya terbit dalam bahasa Inggeris tapi juga dalam bahasa Jerman. Pattaya Mail juga menerbitkan Chiang Mai Mail, koran Pertama Bahasa Inggris di Chiang Mai. Media ini juga memproduksi dan mempublikasikan Publikasi khusus dan menerima usaha-usaha lainnya.

Kepemilikan media ini seratus persen di tangan orang Thailand yaitu Pratheep S. Malhotra, ---keturunan India yang lahir di Phitsanulok dan anak dari pebisnis yang sukses. Sedangkan pengelola seniornya terdiri dari para eksptriat asing seperti Daniel M. Dorothy, Andy Gombaez, Chuck Pringle, Elfi Seitz, Martin Bilsborrow, Dr Iain Corness dll. ditambah staf lokal lainnya. Menurut Pratheep S. Malhotra, pilihannya membuka koran berbahasa Inggeri dan kemudian bahasa Jerman karena ia melihat ada peluang bisnis dimana saat itu kedua negara tersebut menjadi turis dominan di Pattaya ${ }^{33}$.

Dari latar tersebut dapat kita simpulkan bahwa aspek bisnis nampak lebih dominan dari dinamika media ini. Ini mempengaruhi cara media ini dalam merepresentasikan sesuatu termasuk di dalamnya isu radikalisme agama dan ISIS misalnya. Ditambah lagi meski Pratheep S. Malhotra ber-KTP Thailand tapi darah "asing" dalam dirinya membuatnya terbebas dari belengguh sentimen terhadap penduduk

${ }^{33}$ Lihat di http://www.pattayamail.com/1042/Specialpm2.shtml 
kawasan Thailand Selatan sebagaimana orang lokal. Meski demikian, Malhotra tak terhindari dominasi akspatriat asing yang mengelolah media ini. Hal itu dapat dilihat pada pemberitaan Pataya Mail yang berjudul Army Chief Assertsno Isis in Thailand (Panglima militer menegaskan tidak ada ISIS di Thailand) ${ }^{34}$ Berikut hasil analisa Wacana model Theo Van Leuween pada artikel tersebut:

Tabel 3: Hasil Analisa Wacana pada Pattaya Mail

\begin{tabular}{|c|c|c|}
\hline Judul Artikel & Media & $\begin{array}{c}\text { Bagaimana Aktor/ Subjek } \\
\text { diwacanakan }\end{array}$ \\
\hline $\begin{array}{l}\text { Panglima Militer } \\
\text { Menegaskan Tidak Ada } \\
\text { ISIS di Thailand }\end{array}$ & Pattaya Mail & $\begin{array}{l}\text { Pertama, pada artikel ini, subjek yang } \\
\text { terkait dengan ISIS digambarkan } \\
\text { dengan menggunakan strategi } \\
\text { nominasi-kategorisasi, Subjek tidak } \\
\text { hanya disebut ISIS tapi juga } \\
\text { diterangkan sebagai "kelompok } \\
\text { militan" juga sebagai 'ancaman'. } \\
\text { Kedua, Subjek digambarkan dengan } \\
\text { strategi asosiasi-disasosiasi, dalam } \\
\text { konteks ini, ISIS tidak hanya } \\
\text { ditempatkan sebagai musuh Thailand } \\
\text { tapi juga sebagai musuh bersama } \\
\text { (common enemy) yang mengancam } \\
\text { integrasi dan keamana negara kawasan } \\
\text { Asean lainnya. Karena itu, berbeda } \\
\text { dengan The Bangkok Post, media ini } \\
\text { tidak mengaitkan sama sekali subjek } \\
\text { yang terkait ISIS dengan Thailand } \\
\text { Selatan. }\end{array}$ \\
\hline
\end{tabular}

Artikel di atas terbit pada 26 Nopember 2014. Berbeda dengan artikel The Bangok Post sebelumnya yang diterbitkan pada tanggal 12 Juni 2015 yang menyatakan ISIS sudah masuk Thailand, pada artikel yang diterbitkan sekitar setengah tahun sebelumnya ini memberitakan tentang ISIS yang dikatakan belum menunjukkan tanda-tanda masuk ke Thailand. Lewat subjek yang bernama Jenderal Udomdej Sitabutr, Kepala Angkaan Darat Thailand, diberitakan bahwa Thailand masih aman dari ISIS. Berbeda dengan The Bangkok Post, yang memasukkan subjek atau aktor

\footnotetext{
${ }^{34}$ Artikel dapat dilihat di

http://www.pattayamail.com/?s=Army+chief + asserts + no + isis + in + thailand
} 
anonim yaitu: sumber-sumber intelijen, pada artikel Pattaya Mail di atas tidak tidak terindikasi melakukan hal yang serupa.

Jika dilihat dari kepentingan media, pemberitaan tentang ISIS yang belum masuk ke Thailand dari aspek bisnis tentu akan lebih positif bagi bisnis media dibandingkan jika diberitakan ISIS sudah masuk Thailand. Pattaya Mail berkepentingan menegaskan hal tersebut karena bisnis mereka sangat terkait dan bergantung pada orang-orang asing, baik sebagai pengelolah maupun konsumen mereka. Ini berbeda dengan The Bangkok Post yang secara terang menjelaskan keterkaitan aktivis Thailand Selatan dengan kelompok radikal seperti ISIS demi kepentingan klaim Bangkok atas wilayah Selatan. Hal ini menunjukan bahwa representasi media sangat ditentukan oleh kepentingan, agenda setting media, dan ideologi kelompok dominan ${ }^{35}$.

Di samping itu, pada artikel di atas, subjek yang terkait dengan ISIS digambarkan dengan menggunakan strategi nominasi-kategorisasi. Strategi ini sering kali terjadi pilihan apakah aktor atau pelaku ditampilkan apa adanya atau dikatagorikan (agama, status, bentuk fisik, dsb). Salah satu cap yang diberikan pada aktor yang terkait dengan ISIS pada artikel tersebut adalah cap sebagai "kelompok militan". Bahkan, dalam teks sendiri secara eksplisit menerangkan bahwa mereka sebagai "ancaman", tidak hanya untuk Negara Gajah Putih tersebut tapi juga untuk negara kawasan Asean lainnya.

Namun, berbeda dengan artikel The Bangkok Post sebelumnya, yang menjadikan isu ISIS untuk memarjinalkan kaum muslim pemberontak di kawasan Thailand Selatan, pada artikel Pattani Mail ini marjinalisasi hanya terjadi pada subjek yang menyangkut ISIS semata yang dikategorisir sebagai kelompok militan yang berbahaya dan mengancam keamanan Thailand dan negara-negara Asean lainnya. Pada titik ini asosiasi-disasosiasi juga digunakan, yaitu suatu strategi yang berhubungan dengan pertanyaan apakah aktor atau suatu pihak ditampilkan secara sendiri atau ia dihubungkan dengan kelompok lain yang lebih besar. Dalam konteks ini, ISIS tidak hanya ditempatkan sebagai musuh Thailand tapi juga sebagai musuh bersama (common enemy) yang mengancam integrasi dan keamana negara kawasan Asean lainnya. Dengan strategi ini, Pattani Mail berusaha mengasosiasi negara-

\footnotetext{
${ }^{35}$ Lihat, Norman Fairclough, Language and Power (London: Longman, 1989).
} 
negara Asean untuk bersama-sama menghadapi ISIS sebagai ancaman yang riel yang meski Thailand sendiri belum disusupi kelompok tersebut, tapi ditengarai sudah masuk ke kawasan negara-negara tetangga negeri Gajah putih tersebut yakni negara-negara di kawasan Asia Tenggara.

Artikel di atas juga menggunakan strategi nominasi-abstraksi, yaitu suatu strategi wacana yang berhubungan dengan pertanyaan apakah informasi mengenai suatu peristiwa atau aktor sosial ditampilkan dengan memberikan petunjuk yang konkret (jelas) atau abstraksi (samar-samar). Dalam konteks ini, pada artikel di atas terasa abstrak, kabur dan tidak jelas terutama menyangkut negara tetangga mana saja yang sudah diinfiltrasi oleh paham radikal ISIS, artikel tersebut tidak menyebutkan. Hal ini, tentu dengan pertimbangan untuk kepentingan upaya untuk menciptakan "koalisi besar" negara Asean yang berasosiasi untuk menjadikan ISIS sebagai musuh bersama. Di samping itu, tentu saja untuk menjaga perasaan negara tetangga, karena koalisi besar tersebut bisa saja akan rusak manakala media menyebut secara eksplisit negara tetangga yang bersangkutan.

Kesimpulannya adalah, berbeda dengan The Bangkok Post yang menjadikan kasus ISIS sebagai jalan untuk memarjinalkan umat Islam kawasan Selatan Thailand, pada artikel Pattaya Mail di atas lebih memilih strategi makro, yaitu upaya untuk merangkul sebanyak mungkin teman untuk menghadapi musuh bersama, yaitu apa yang disebut dengan ISIS. Pattaya Mail sengaja tidak mengaitkan isu ISIS pada kalangan pejuang muslim Thailand Selatan karena dianggap hanya akan melemahkan upaya membangun integrasi dan asosiasi besar vis a vis ISIS. Dengan demikian diharapkan upaya pencegahan masuknya kelompok ISIS di negeri Gajah putih tersebut akan mendapat dukungan secara luas, baik nasional maupun internasional, dari dalam maupun dari luar Thailand.

\section{E. Kesimpulan}

Dengan demikian dapat disimpulkan bahwa discourse gerakan ISIS di media disetir oleh motif ekonomi, ideologi dan kepentingan kelompok dominan. Sebagaimana pendapat Wodak, discourse tidak bisa dilepaskan dari relasi kekuasaan dan ideologi ${ }^{36}$. Dalam konteks ini ada selubung kepentingan kekuasaan dalam discourse yang menyangkut

\footnotetext{
${ }^{36}$ Ruth Wodak, Disorders of Discourse, (London: Longman, 1996).
} 
gerakan ISIS dalam media-media di Thailand: The Bangkok Post dan Pattaya Mail. Media menjadi arena representasi dari pelbagai ideologi dan kepentingan kekuasaan. Karena itu, media menjadi alat untuk mendapat legitimasi dan hak-hak istimewa melalui representasi media untuk menggiring opini publik . Melalui representasi media, apa yang disebut oleh Gramsci ${ }^{37}$ sebagai popular common sence menjadi dasar hegemoni yang dimanfaatkan untuk kepentingan kelas dominan dan legitimasi status quo.

Demikianlah, dari kajian ini dapat disimpulkan bahwa Mediamedia di Thailand; yaitu The Bangkok Post dan Pattaya Mail merepresentasikan wacana ISIS dalam bentuk representasi sebagai berikut:

1. Pada The Bangkok Post, merepresentasikan ISIS identik dan sama berbahanya dengan pemberontak muslim di Selatan Thailand. Isu ISIS menjadi jalan untuk memarjinalkan kaum muslim pemberontak di kawasan Thailand Selatan di negeri yang berbatasan dengan Semenanjung Malaya tersebut.

2. Pada artikel Pattaya Mail di atas lebih memilih strategi makro, yaitu upaya untuk merangkul sebanyak mungkin teman untuk menghadapi musuh bersama, yaitu apa yang disebut dengan ISIS. Pattaya Mail sengaja tidak mengaitkan isu ISIS pada kalangan pejuang muslim Thailand Selatan. Meski demikian media ini tetap menganggap ISIS sebagai gerakan militan dan mengancam keamanan kawasan Asean. Karena itu, ISIS menjadi ancaman bersama.

\section{DAFTAR PUSTAKA}

Althusser, Louis, 2012, Ideology and Ideological State Apparatus (Notes Towards an Investigation) ed. S. Zizek dalam Mapping Ideology, London - Newyork: Verso.

Barker, Chris, 2009, The SAGE Dictionary of Cultural Studies, London: Sage.

Choirol Ummah, Sun, 2012, "Akar Radikalisme Islam di Indonesia”, Jurnal Humanika, Vol. 2, No. 12.

\footnotetext{
${ }^{37}$ Antonio Gramsci, Selections from the Prison Notebooks, (New York: International Publishers, 1971).
} 
Chomsky, Noam, 2003, Hegemony or Survival, New York: Metropolitan Books.

Durkheim, Emile, 1982, The Rules of the Sociological Method, New York: Free Press.

Elgambri, Elzain, 2008, Islam in The British Broadsheets: The Impact of Orientalism on Representation of Islam, Reading UK: Itaca.

Fairclough, Norman dan Wodak, Ruth, 1997, Critical Discourse Analysis: An Overview, dalam Discourse and Interaction, ed. Teun van Dijk, London: Sage Publications.

Fairclough, Norman, 1989, Language and Power, London: Longman.

Foucault, Michel, 1980, Power/knowledge: Selected Interviews and Other Writings, 1972-1977, New York : Harvester Wheatsheaf.

Gramsci, Anthony, 1971, Selections from the Prison Notebooks, New York: International Publishers.

Hall, Stuart, 1997, Representation: Cultural Representations and Signifying Practices, London Thousand Oaks, California: Sage.

Ibrahim Khaidar, Latifah, 2005, Ketika Barat Memfitnah Islam, terj. Abdul Hayyie, Jakarta: Gema Insani Press.

Ibrahim, Malik, 2012, Seputar Gerakan Islam di Thailand Suatu Upaya Melihat Faktor Internal dan Eksternal, Jurnal SOSIO-RELIGIA, Vol. 10, No.1.

Khuriyati, 2013, Analisis Wacana Terhadap Teks Berita Tuntutan Pembubaran FPI pada SKH Kompas edisi Februari 2012, "Skripsi", Yogyakarta: UIN Sunan Kalijaga.

Kleden, Leo 1997, “Teks, Cerita dan Transformasi Kreatif”, Jurnal Kebudayaan Kalam, Vol.2, No. 10.

Lul, J., 1998, Media Komunikasi Kebudayaan: Suatu Pendekatan Global, terj. A. Setiawan Abadi, Jakarta: Yayasan Obor Indonesia.

Maftukha, Laili, 2011, Gerakan Pembebasan Islam Pattani di Thailand Selatan pada tahun 1973-1982, Skripsi, Surabaya: Fakultas Adab Institut Agama Islam Negeri Sunan Ampel.

Mills, Sara , 2003, Michel Foucault, London: Routledge. 
Munip, Abdul, 2012, "Menangkal Radikalisme di Sekolah", Jurnal Pendidikan Islam Vol. 1, No.2.

Prima Damayanti, Ninin, et al., 2012 "Radikalisme Agama Sebagai Salah Satu Bentuk Perilaku Menyimpang: Studi Kasus Front Pembela Islam”, Jurnal Kriminologi Indonesia, Vol. 3, No. 1.

Said, Edward , 1997, Covering of Islam: How the Media and Experts Determine How We See the Rest of the World, Newyork: Vintage.

Sara Mills, ed., 1997, Discourse, London: Routledge.

Simmel, G., 2011, On Individuality and Social Forms, Chicago: University of Press.

Spivak, G.C., 1990, The Post-Colonial Critic: Interviews, Strategies, Dialogies, London: Routledge.

Sunardi, St., 1996, Nietzsche, Yogyakarta: LKiS.

Ummah, Sun Choirol, 2012, Akar Radikalisme Islam di Indonesia, Humanika, Vol. 2. No. 12.

Van Dijk, Teun (ed.), Discourse and Interaction, (London: Sage Publications).

Van Leeuwen, T., 1996. The Representation of Social Actors in Discourse, dalam Texts and Practices: Readings in Critical Discourse Analysis, ed. C. R. Caldas-Coulthard, \& M. Coulthard, London: Routledge.

Vass, E., 1992, Duskursanalyse als Interdisiplinares Forschungsgebiet, Wien: Universitas Wien Diplomarbeit.

Wardhani, Baiq L S W, 2010, Globalisasi dan konflik etnis (Surabaya : Cakra Studi Global-Strategis (CSGS) Publisher.

Wodak, Ruth, 1996, Disorders of Discourse, London: Longman. 